\title{
Diversity and abundance of water birds in a subarctic lake during three decades
}

\author{
Anders Klemetsen' and Rune Knudsen'
}

\begin{abstract}
Klemetsen A and Knudsen R. 2013. Diversity and abundance of water birds in a subarctic lake during three decades. Fauna norvegica 33: 21-27.

The numbers of divers, ducks, gulls, terns and waders in the $15 \mathrm{~km}^{2}$ oligotrophic lake Takvatn, North Norway, were estimated six times during 1983-2012. Systematic mapping surveys were done by boat within the first week after the ice-break in June. Twenty-one species were observed over the years and 12 were regarded as breeding on the lake. Red-breasted merganser Mergus serrator was the dominant diving bird, with the estimated minimum number of breeding pairs varying from 15 to 39 among the years. Black-throated diver Gavia arctica (1-3 pairs), tufted duck Aythya fuligula (2-15 pairs) and common scoter Melanitta nigra (1-5 pairs) bred regularly, while velvet scoter Melanitta fusca (1-2) and goldeneye Bucephala clangula (2-4) were found in some years and mallard Anas platyrhynchos (1 pair) and wigeon Anas penelope (1 pair) in one year. Common gull Larus canus (6-30 pairs) and arctic tern Sterna paradisaea (2-35 pairs) bred in all years. Common sandpiper Tringa hypoleucos (3-9 pairs) and redshank Tringa totanus (1-4 pairs) were regular waders. Density variations of mergansers, gulls and terns are possibly related to density variations of threespine stickleback Gasterosteus aculeatus, their dominant fish prey. As predators and parasite hosts, the water birds are important links in the food web of the lake.
\end{abstract}

doi: 10.5324/fn.v33i0.1584. Received: 2013-05-03. Accepted: 2013-09-11. Published online: 2013-12-20.

Keywords: water birds, abundance, subarctic lake, food web

1. Freshwater Ecology Group, Department of Arctic and Marine Biology, University of Tromsø, Breivika, N-9037 Tromsø, Norway.

Corresponding author:Anders Klemetsen

E-mail: anders.klemetsen@uit.no

\section{INTRODUCTION}

Density estimates of Norwegian water birds are rarely done in low production lakes, but the long-term studies in the mountain lake Øvre Heimdalsvatn in south Norway (Brittain \& Borgstrøm 2010) included bioenergetic calculations for ducks based on repeated counts in the ice-free season (Lien 1978). In northern Norway, a general overview of wetland birds in Troms County is given in the book by Strann and Bakken (2004) on the breeding birds of the county. In addition, there are detailed reports on the status of horned grebe Podiceps auritus (Linnaeus, 1758) in Troms (Strann \& Frivoll 2009, Strann et al. 2010, 2013). In 1972-76, a large-scale aerial survey of waterfowl was conducted in northern Finland, Sweden and parts of northern Norway (Haapanen \& Nilsson 1979). A massive effort with small aircraft was set in, but the results were limited to waterfowl (Anatidae), i.e. swans and ducks (geese were excluded), not other groups of water birds, and were based on transects at a regional scale. Important results from counts of water birds in the Pasvik river system in Finnmark County from 1996-2005 are given by Günther (2006). The report provides a general status of all water birds in Pasvik, but there is little information on the sizes of the populations of the species that breed in the system. To our knowledge (and confirmed by KarlBirger Strann at NINA; pers. comm.), no surveys of all water birds are published for any lake in northern Norway.

Here, we present results from quantitative surveys of water birds undertaken six times over a period of 30 years in the 15 $\mathrm{km}^{2}$, oligotrophic lake Takvatn in the Målselv river system in 
Troms, northern Norway. The purposes were, first, to produce a checklist of water birds for Takvatn and, second, to estimate the population densities of the species that breed on the lake, and their variation over time. Moreover, it became particularly important to obtain information on the water bird community for the food web studies that are now implemented in the lake (Amundsen et al. 2009, 2013).

\section{Takvatn}

Takvatn is an oligotrophic lake situated at $69^{\circ} 07^{\prime} \mathrm{N}$ in the Målselv drainage, Troms County, at $214 \mathrm{~m}$ a.s.l. in a landscape of birch (Betula) woods with some willows (Salix), alder (Alnus) and pine (Pinus), and treeless mountains higher in the catchment area. The ground vegetation along the shores is mainly Vaccinium/Empetrum dwarf shrubs (as defined by CAVM Team 2003). There are two active dairy farms and a number of holiday cabins. The lake is about $7.5 \mathrm{~km}$ long and about $2(1.7-2.5) \mathrm{km}$ wide. The surface area is $15 \mathrm{~km}^{2}$ and the lake has two basins of about the same size, both with maximum depths of $80 \mathrm{~m}$. There are eight islands ( $>100 \mathrm{~m}$ in one dimension) and about 25 smaller islands and islets, especially in the shallow area in the middle of the lake. The length of the shoreline with the islands included is $32 \mathrm{~km}$. Takvatn is normally ice-bound from early December to June but the ice-break varies by several weeks among years. Maximum epilimnic temperatures are about $14^{\circ} \mathrm{C}$ and Secchi disc transparencies vary between 12 and $17 \mathrm{~m}$. Total $\mathrm{P}$ concentrations never exceed $5 \mu \mathrm{g} \mathrm{l^{-1 }}$ and the lake is well oxygenated with a $\mathrm{pH}$ around 7.

The littoral zone extends to about $15 \mathrm{~m}$ depth and covers about one third of the lake area. Due to strong wave action from wind fetches of $2 \mathrm{~km}$ or more, most shores of the lake have hard bottom substrata of sand, gravel, stones and rocks, and no macro-vegetation down to about $3 \mathrm{~m}$ depth. For a large part, waves also prevent vegetation on land close to the water. The exception is one protected bay (Langkjosen) which has scattered helophytes of horsetails (Equisetum) and sedges (Carex). The lower littoral has a macrophyte belt dominated by stoneworts (Nitella) but also scattered stands of water-milfoils (Myriophyllum), pondweeds (Potamogeton), quillworts (Isoëtes) and mosses in the 3-15 depth zone.

The fishes in the lake are Arctic charr Salvelinus alpinus (Linnaeus, 1758), brown trout Salmo trutta Linnaeus, 1758 and threespine stickleback Gasterosteus aculeatus (Linnaeus, 1758). Several aspects of the lake ecology have been studied extensively from 1980 (Dahl-Hansen 1995, Primicerio 2000, Knudsen et al. 2002, Klemetsen et al. 2003, Amundsen et al. 2007, 2009 and 2013 and references therein). An experimental mass removal of charr was done by heavy fishing in 1984-89 (Klemetsen et al. 2002). This changed the density, growth and population structure of charr profoundly and also affected the populations of trout and sticklebacks (Klemetsen et al. 2002, Persson et al. 2007, Amundsen et al. 2007).

\section{METHODS}

Surveys of water birds, i.e. divers, ducks, gulls, terns and waders, were done once each year in 1983,1988,1992,1993, 2003 and 2012, i.e., six times during 30 years. The years were chosen at random, but the surveys were always conducted within the first week after the ice-break. During this early phase of the breeding season, pair bonds are strong and breeding territories are established but most of the species have still not started laying of eggs. If they have, they do not sit on the nest to brood because the clutches are not complete, and the females are seen on the lake along with the males most of the time. The discovery chance (Seierstad et al. 1965) for breeding pairs is high at this time. The first few days after ice-break are therefore the best time for obtaining good density estimates of ducks and divers (Haapanen \& Nilsson 1979). Gulls and terns breed in single pairs or in loose colonies at the lake, mostly on islands but also on the shores. Nesting starts around or just after ice-break, as soon as there are areas without snow on the ground. As the vegetation growth has just started, they were clearly seen on their nesting sites at this time. Likewise, waders were also easy to observe along the shores and on the islands.

The surveys were done by moving systematically at moderate speeds with an outboard-powered boat along the shores and around the islands. Starting in the morning, we chose a day with little wind and no precipitation in order to achieve good observing conditions. Survey times varied between two and two-and-one-half hours among years. Except for the first year when one man was alone, two observers equipped with good binoculars conducted the surveys. All birds were identified to species and sex (for ducks), and their position noted on a map. Both observers always confirmed the identifications. If divers or ducks were flushed, the flight was followed as far as possible and the direction and landing position noted. Most often, they flew a short distance or came back after moving in a curve. Divers, but usually not ducks, often dived away when disturbed. We took caution to avoid double observations, and had very few doubtful cases. If in doubt, we took out possible double notations. Ducks and divers were most often observed in pairs, and their numbers taken as minimum estimates of breeding pairs. Single birds of both sexes were taken to indicate possible breeding pairs, and were counted in the maximum estimates. We considered additional males that occasionally were observed along with duck pairs, and two or more divers or male ducks that were seen together a few times, to be nonbreeding birds and did not include them in the estimates. Single or paired gulls and terns sitting on the ground were taken to indicate breeding and counted as minimum estimates of breeding pairs. Gulls and terns often took to the wing when the boat came close to the colonies. Their numbers divided by two were included in the maximum estimates. Single birds and pairs that were flushed or seen on the shores were used to estimate the number of breeding pairs of waders. Our methods followed standard methods for quantitative water bird surveys closely 
(Nilsson 1978, 1985).

Apart from the obvious result of finding nests or observing broods, we set two conditions for regarding a species as breeding on the lake. The first was that pairs, not only single birds, should be seen during the surveys. This removed rare species that visited the lake more or less by chance. The second was that the species should be observed on the lake later in the season. Such observations were noted throughout the season during fieldwork on fish, plankton and benthos. This took out species that, even if they occurred in pairs, were on their way to other breeding habitats that were not accessible at this time, such as mountain lakes that were still not ice-free.

\section{RESULTS}

Twenty-one species of water birds were observed on Takvatn over the six years of surveys. These were two divers, two dabbling ducks, five diving ducks, two mergansers, five waders, one skua, three gulls and one tern (Table 1). Redthroated diver, arctic skua and some waders and gulls were not considered as breeding on the lake as they were mostly observed as single birds, and never later in the season. The remaining 12 species were observed on the lake later during the season, often with broods and some with nests, and therefore considered as breeding on the lake.

Six species: black-throated diver, tufted duck, common scoter, red-breasted merganser, common gull and arctic tern were present all years (Table 2). Two wader species, redshank

Table I. Checklist of water birds observed at Takvatn during surveys 1983-2012. Numbers are total $\mathrm{N}$ over all years with the number of years observed in brackets.

Black-throated diver Gavia arctica (Linnaeus, 1758) $.41(6)$

Red-throated diver Gavia stellata (Pontoppidan, 1763) . $.3(2)$

Mallard Anas platyrhynchos Linnaeus, 1758 ...................................... 2 (1)

Wigeon Anas penelope Linnaeus, 1758 .............................................. (1)

Tufted duck Aythya fuligula (Linnaeus, 1758) ..................................82 (6)

Common scoter Melanitta nigra (Linnaeus, 1758) ..........................42 (6)

Velvet scoter Melanitta fusca (Linnaeus, 1758).................................10 (3)

Long-tailed duck Clangula hyemalis (Linnaeus, 1758) ......................4 (3)

Goldeneye Bucephala clangula (Linnaeus, 1758) ............................10 (2)

Red-breasted merganser Mergus serrator Linnaeus, 1758...............385 (6)

Goosander Mergus merganser Linnaeus, 1758..................................7 (2)

Ruff Philomachus pugnax (Linnaeus, 1758)...................................... 1 (1)

Redshank Tringa totanus (Linnaeus, 1758)........................................11 (4)

Common sandpiper Tringa hypoleucos Linnaeus, 1758 ....................29 (4)

Whimbrel Numenius phaeopus (Linnaeus, 1758)...............................2 (1)

Red-necked phalarope Phalaropus lobatus (Linnaeus, 1758 ..............2 (1)

Arctic skua Stercorarius parasiticus (Linnaeus, 1758).......................2 (2)

Black-headed gull Larus ridibundus Linnéaeus, 1758 ........................2 (1)

Common gull Larus canus Linnaeus, 1758 ....................................231 (6)

Herring gull Larus argentatus Linnaeus, 1758................................... 1 (1)

Arctic tern Sterna paradisaea Pontoppidan, 1763 ...........................121 (6)
Table 2. Breeding pairs of water birds at Takvatn 1983-2012. Two numbers indicate minimum and maximum estimates. Waders were not counted the first two years.

\begin{tabular}{lcccccc}
\hline & 1983 & 1988 & 1992 & 1993 & 2003 & 2012 \\
\hline $\begin{array}{l}\text { Black-throated } \\
\text { diver }\end{array}$ & 2 & 1 & 2 & 2 & 2 & 3 \\
Mallard & - & - & - & - & 1 & - \\
Wigeon & - & - & - & - & $1-3$ & - \\
$\begin{array}{l}\text { Tufted duck } \\
\text { Common }\end{array}$ & 5 & 2 & 8 & $4-5$ & $15-16$ & 6 \\
$\begin{array}{l}\text { scoter } \\
\text { Velvet scoter }\end{array}$ & - & 2 & - & - & $1-3$ & 2 \\
$\begin{array}{l}\text { Goldeneye } \\
\text { Red-breasted }\end{array}$ & - & - & - & 2 & 4 & - \\
merganser & $17-21$ & $15-18$ & $39-60$ & $25-34$ & $30-45$ & $25-37$ \\
$\begin{array}{l}\text { Redshank } \\
\text { Common }\end{array}$ & & & 1 & 1 & 1 & 4 \\
$\begin{array}{l}\text { sandpiper } \\
\text { Common gull }\end{array}$ & $15-22$ & $20-30$ & $30-36$ & $25-28$ & $29-33$ & $6-14$ \\
Arctic tern & 5 & $8-15$ & $35-40$ & $12-15$ & $15-17$ & 2 \\
\hline
\end{tabular}

and common sandpiper occurred the last four years (but waders were not counted the first two years). Four other ducks: mallard, wigeon, velvet scoter and goldeneye occurred in some (one to three) years.

With estimated densities of 15 pairs or more (Table 2), redbreasted merganser was by far the most common diving bird on the lake. Their numbers varied considerably among years, from 15-18 pairs (minimum and maximum estimates) in 1988 to 39-60 pairs in 1992 and 30-54 pairs in 2003. The number of pairs per km shoreline varied among years between $0.5-1.2$ (minimum estimates) and 0.6-1.9 (maximum estimates). The estimated densities of the other two diving ducks that occurred in all years, tufted duck and common scoter, were much lower and always below 10 pairs (except for the exceptionally high number of 15-16 pairs of tufted ducks in 2003). Again, the numbers varied much among years with estimates for the minimum number of pairs at between 1 and 6 pairs of common scoters and 2 and 15 pairs of tufted ducks. This gives a variation of pairs per km shoreline of 0.1-0.5 (minimum and maximum values) for tufted duck and $<0.1-0.3$ for common scoter. The last two diving ducks, velvet scoter and goldeneye, were observed in some years and the dabbling ducks mallard and wigeon occurred only one year. Goldeneye started breeding at Takvatn when four nesting boxes were put up in 1992. Black-throated divers were present in all years but the estimates were always low, varying between one and three pairs. We found two nests with eggs in 2012, both on islands. The common gull was the second most numerous bird on the lake. The densities exceeded the density of mergansers in 1988 and were about equal in 1993, but were below in the other years (Table 2). The number of pairs (minimum and maximum estimates) varied from 6-14 in 2012 
to 30-36 in 1992. The arctic tern was the most variable of all species, with only 2 pairs in 2012 and as high as 35-40 pairs in 1992. The common sandpiper was the more numerous of the two waders that occurred regularly, with 3-9 estimated pairs.

Red-breasted mergansers were found over the entire lake in all years but there was always a tendency that more pairs were seen in the north basin and along the east side of the south basin, as can typically be seen from 2012 (Figure 1). Tufted ducks and common scoters were also most often found along the east side. There was a colony of common gulls on the largest island in the middle of the lake on the east side (Figure 1) every year but also single pairs all over the lake. Using three islets in the northeast part of the lake (Figure 1), terns had two colonies in 1992 and one colony the other years, except for 2012 when there was none.

\section{DISCUSSION}

Takvatn is an oligotrophic lake with wave-washed shores situated in a woodland landscape. This is not a very attractive environment for water birds and the rather limited checklist of 21 species was as could be expected. Moreover, nine of them

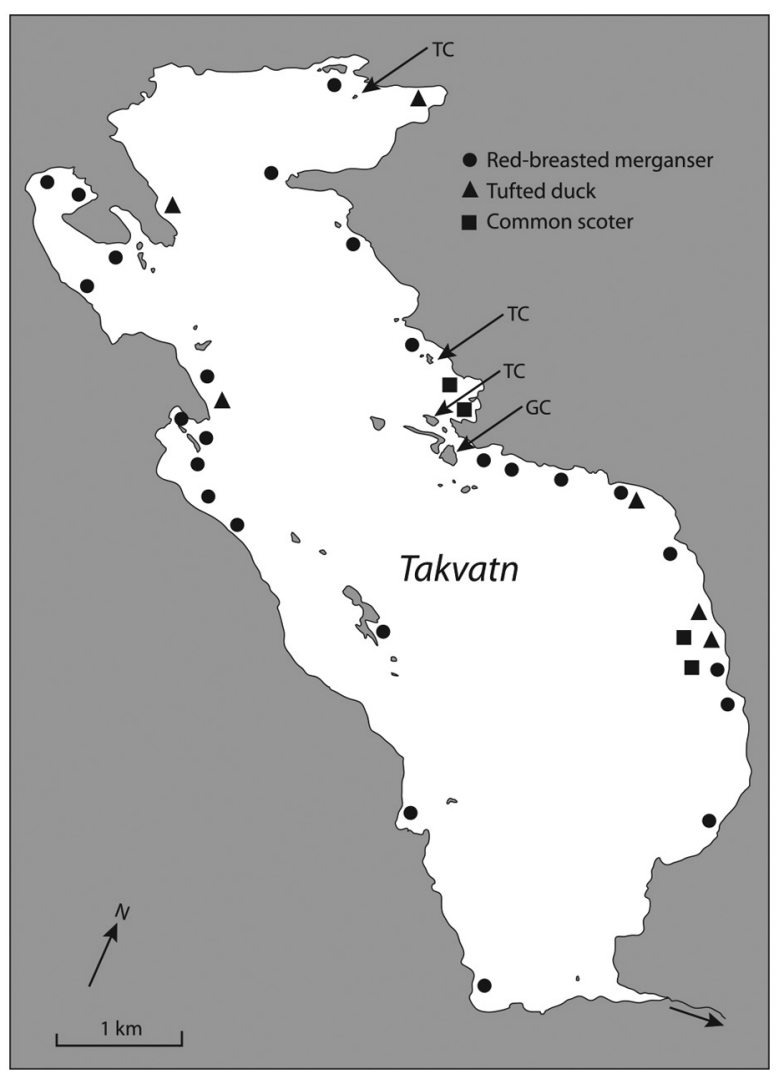

Figure I. Distribution of pairs of the diving ducks red-breasted merganser, tufted duck and common scoter in Takvatn, June 2012. TC: colonies of arctic terns; GC: colony of common gulls. Drawn by Frøydis Strand. were not considered to breed. In contrast, the more productive Pasvik river system in eastern Finnmark has 97 species, 48 of them breeding (Günther 2006). This system has a series of large and shallow lakes with varied habitats and well-developed wetlands. The non-breeding species at Takvatn included single sea birds and waders, and long-tailed duck and goosander that most likely were on their way to breeding areas elsewhere. The distance from the sea is about $15 \mathrm{~km}$. This is probably too far for straying sea birds, and very few were observed. The only common sea birds (common gull and arctic tern) bred on the lake itself. These two species frequently breed in freshwater in Troms (Strann \& Bakken 2004). Apart from a small area in one protected bay, there are no wetlands along the lake. This lack of suitable habitats severely restricts the number of waders, so only two species (redshank and common sandpiper) breed and few others were observed. The dabbling ducks mallard and wigeon do not dive for food and are herbivorous (wigeon) or omnivorous with a preference for plants (mallard) (Haftorn 1971). They prefer protected shores where they can feed on vegetation in shallow water or on land if there are suitable food plants close to the water. Such habitats are rare on the stony shores of the lake, and dabbling ducks were only observed in one year. Again, this is very poor compared to results from other northern systems (Haapanen \& Nilsson 1979, Günther 2006), where dabbling ducks very often are diverse and abundant but quite similar to the oligotrophic mountain lake Øvre Heimdalsvatn, South Norway, that had only two species of dabbling ducks but eight species of diving ducks (Lien 1978).

Strann et al. (2012) observed horned grebes in Takvatn in some years. This species prefer to breed in small lakes and tarns with well-developed shore vegetation (Strann \& Bakken 2004). Several breeding localities are known to be a few $\mathrm{km}$ from the lake (Strann et al. 2012) and they probably come occasionally to the lake to feed. Karl-Birger Strann (pers. comm.) observed scaup Aythya marila (Linnaeus, 1758) a few times on Takvatn during fieldwork on grebes. This species breeds commonly in mountain lakes, but sometimes also in woodland lakes especially if there are islands (Strann \& Bakken 2004). It is therefore possible that it breeds on the lake in some years. Red-throated divers were sometimes seen during the surveys however, like the horned grebe, the species probably breeds in small lakes or tarns in the watershed and comes to the lake to feed.

The community of breeding birds at Takvatn was relatively stable throughout the study period of 30 years. True, some of the less common species were not observed every year but apart from mallard and wigeon that were only observed in one year, they occurred over the entire period. For the coastal and inlands regions of Troms, Haapanen \& Nilsson (1979) found the same abundance range among the three common diving ducks (red-breasted merganser followed by tufted duck and common scoter) as we did, but the densities were higher in Takvatn. Given as pairs per km shoreline, the regional densities were 0.33 (coast) and 0.29 (inland) for red-breasted merganser, 0.11 
(coast) and 0.07 (inland) for tufted duck and not more than 0.03 for common scoter. For two regions in Sweden and Finland across the border from Troms, the values were 0.03 and 0.05 for red-breasted merganser, 0.18 and 0.17 for tufted duck and 0.01 and 0.01 for common scoter. The respective values for the three species at Takvatn were $0.5-1.9,0.1-0.5$ and 0.03 - 0.3. Some of these differences may be related to method, but Haapanen \& Nilsson (1979) used correction factors from air/ ground comparisons in selected lakes to adjust their numbers. It is however difficult to compare the results from one lake with the values for entire regions, as the regional values are averages that say nothing about local variation. Even so, it is interesting that the densities from Takvatn are clearly higher than the regional averages for Troms for these species, also when variation among years are accounted for. They were also clearly higher than in the border regions of Sweden and Finland for red-breasted merganser and common scoter. The values for tufted duck across the border were within the range for Takvatn, but the maximum values were higher in Takvatn. The abundances of the three common diving ducks therefore seem to be higher in Takvatn than the average for Troms and the neighbouring regions in Sweden and Finland. These results indicate that the ecological conditions in Takvatn are well suited for these diving ducks.

The overall most abundant species on the lake, red-breasted merganser, common gull and arctic tern, are all fish-eating birds while the other diving ducks take invertebrates (Haftorn 1971). It is no surprise that the community was dominated by birds that feed on fish and invertebrates. These predators employ two different feeding modes: ducks and divers swim down, often to considerable depths, in their hunt for food while gulls and terns feed at the surface, sometimes by shallow diving. Both feeding modes are well adapted to a lake such as this. In spite of being an oligotrophic lake, Takvatn offers a prey fish, the threespine stickleback, which is attractive for fish-eating birds. This is no doubt the main prey for mergansers, gulls and terns. Sticklebacks were found in the stomach contents of young mergansers that are caught a few times in our gill nets (Roar Kristoffersen, pers. comm.), and feeding birds of the three species were sometimes seen with sticklebacks in their beaks. In addition, indirect evidence comes from the fact that infected sticklebacks transfer larvae of the tapeworm parasites Schistocephalus solidus Müller, 1776 and Diphyllobothrium spp. from fish to birds in their life cycle. Diphyllobothrium can also be transferred by charr and trout but sticklebacks are more important (Knudsen \& Klemetsen 1994; Knudsen et al. 1996). Charr and trout are abundant in a wide size range in Takvatn and are certainly also taken by mergansers, but perhaps more frequently by black-throated divers that can dive deep and take fish up to large sizes.

The mass removal of charr in Takvatn changed the fish community of the lake in a profound way (Klemetsen et al. 2002, Persson et al. 2007, 2013). Before the experiment, the littoral zone had a high density of older but small charr of many year-classes and the younger charr were pushed to deep water and the pelagic zone by intraspecific predation and competition. Sticklebacks were quite common but there were very few trout. After the experiment, trout became much more abundant and both salmonids showed good growth and attained sizestructured populations (Klemetsen et al. 2002, Amundsen et al. 2007, Persson et al. 2007, 2013). We believe that the density of sticklebacks started to fluctuate more than before due to these changes. A strong population peak came in 1991 and the density was still high in 1992 (Klemetsen et al. 2002), the year with the highest abundances of mergansers, gulls and terns (Table 2). Notably, Dahl-Hansen (1995) found that sticklebacks moved out into the pelagic zone in 1991 and 1992 as a direct result of a competition release from charr that left that habitat in preference for the littoral. Terns were seen fishing for sticklebacks all over the lake in those years, and this coincided nicely with their strong density increase from 1988 to 1992.

The other diving ducks are all predators on macroinvertebrates (Haftorn 1971). Before the extensive fishing, the very dense charr population had taken the abundances of attractive prey in the littoral zone, such as snails, amphipods and large insect larvae, down to very low levels. Such prey were rarely found in the fish stomachs at that time (Amundsen \& Klemetsen 1988), but came back as a result of the stock reduction of charr (Klemetsen et al. 2002, unpublished data). They continue to have reasonably high densities in the littoral zone (Klemetsen \& Elliott 2010). We believe that the high density of diving ducks in 2003 (Table 2) is related to this recurrence of attractive macro-invertebrates in the lake. This is supported by experimental studies on competition between fish and ducks in small lakes in Sweden (Eriksson 1979) and England (Giles 1994). In both cases, abundances of macroinvertebrates increased when fish were removed, and this had positive effects on the use of lakes by diving ducks.

All common water birds of Takvatn find suitable breeding habitats at the lake. The islands attract black-throated divers, common gulls and arctic terns because they prefer to breed there in order to reduce predation from mammals. Bushes, shrubs and rocks that are found close to the water along all shores provide good shelter for nesting mergansers and diving ducks. The tendency that mergansers and ducks were more abundant in the north basin and along the east side of the south basin can have several reasons. The shoreline of the north basin is more convoluted than the south basin (Figure 1) and therefore has many relatively protected habitats that are well suited for feeding and breeding. It has long been known that colonies of gulls and terns attract breeding ducks because the aggressive behaviour of the larids provides protection from predators (Hildén 1965). We never went ashore to the colonies in order not to disturb the birds and therefore have no direct evidence for this at Takvatn, but duck pairs were frequently seen close to the colonies in all surveys. Finally, the stretch of shore southwards from the islands on the east side may have good feeding conditions because the littoral zone is wider here than 
elsewhere in the lake.

The bird community of Takvatn is strongly dominated by predators of fish and invertebrates. This is quite different from the general results that waterfowl communities in northern Finland, Sweden and Norway include both plant-eating ducks and predators (Haapanen \& Nilsson 1979). This difference mainly reflects ecological factors. Most landscapes of northern Fennoscandia have wetlands with mires and numerous ponds and small lakes that attract both herbivorous and carnivorous water birds. In contrast, Takvatn is a large lake without shore vegetation but with a very important fish prey, the threespine stickleback. As this species is a poor upstream swimmer, its distribution is largely restricted to coastal areas below the maximum postglacial marine limit. Therefore, it is absent in most of the areas covered by Haapanen \& Nilsson (1979).

The fish-eating birds are at the top (fifth) level in the food web of the pelagic community (Amundsen et al. 2009, 2013) of Takvatn, whereas invertebrate predators are at levels three and four. All bird species are important nodes and have many links in the web. These studies also include parasites. Here, the birds take central positions because they are final hosts for several parasites that are transferred by predation links (Amundsen et al. 2009). Currently, new studies are implemented that focus on the benthic food web of the lake. It is not unlikely that the water birds will be shown to have even more important roles in this more complex web, both as predators and parasite hosts.

\section{ACKNOWLEDGMENTS}

We thank Karl-Birger Strann, Tromsø for valuable information on water birds in Troms and Leif Nilsson, Lund for important literature information. Per-Arne Amundsen and an anonymous reviewer provided constructive comments to the manuscript. The study was supported by the University of Tromsø and the Norwegian Research Council (NFR 213610/F20).

\section{REFERENCES}

Amundsen P-A, Klemetsen A. 1988. Diet, gastric evacuation rate and food consumption in a stunted population of arctic charr (Salvelinus alpinus L.) in Takvatn, northern Norway. Journal of Fish Biology 33: 697-709.

Amundsen P-A, Knudsen R \& Klemetsen A. 2007. Intraspecific competition and density dependence of food consumption and growth in Arctic charr. Journal of Animal Ecology 76: 149-158.

Amundsen P-A, Lafferty KD, Knudsen R, Primicerio R, Klemetsen A, Kuris AM. 2009. Food web topology and parasites in the pelagic zone of a subarctic lake. Journal of Animal Ecology 78: 563-572.

Amundsen P-A, Lafferty KD, Knudsen R, Primicerio R, Kristoffersen R, Klemetsen A, Kuris AM. 2013. New parasites and predators follow the introduction of two fish species to a subarctic lake: implications for food-web structure and functioning. Oecologia 171: 993-1002.

Brittain JE, Borgstrøm R. 2010. The subalpine lake ecosystem. Øvre Heimdalsvatn, and its catchment: local and global changes over the last 50 years. Developments in Hydrobiology 211: 1-126.

CAVM Team. 2003. Circumpolar Arctic Vegetation Map. Conservation of Arctic and Flora and Fauna (CAFF) Map No. 1. Anchorage, Alaska. US Fish and Wildlife Service.

Dahl-Hansen GAP. 1995. Long-term changes in crustacean plankton - the effects of a mass removal of arctic charr Salvelinus alpinus (L.) from an oligotrophic lake. Journal of Plankton Research 17: 1819-1833.

Eriksson MOG. 1979. Competition between freshwater fish and goldeneyes Bucephala clangula (L.) for common prey. Oecologia 41: 99-107.

Giles N. 1994. Tufted duck (Aythya fuligula) habitat use and brood survival increases after fish removal from gravel pits. Hydrobiologia 279/280: 387-392.

Günther M. 2006. Ti år med vannfugltellinger i Pasvik naturreservat. Oppsummering 1996-2005. Bioforsk Rapport 1 (68): 1-65. Haftorn S. 1971. Norges fugler. Oslo. Universitetsforlaget. 862 p.

Haapanen A, Nilsson L. 1979. Breeding waterfowl populations in northern Fennoscandia. Ornis Scandinavica 10: 145-219.

Hildén O. 1965. Habitat selection in birds. A review. Annales Zoologica Fennica 2: 53-75.

Klemetsen A, Amundsen P-A, Grotnes PE, Knudsen R, Kristoffersen R \& Svenning MA. 2002. Takvatn trough 20 years: long-term effects of an experimental mass removal of arctic charr, Salvelinus alpinus, from a subarctic lake. Environmental Biology of Fishes 64: 39-47.

Klemetsen A, Knudsen R, Staldvik FJ, Amundsen P-A. 2003. Habitat, diet and food assimilation of arctic charr under the winter ice in two subarctic lakes. Journal of Fish Biology 62: 1082-1098.

Klemetsen A, Elliott JM. 2010. Spatial distribution and diversity of macroinvertebrates on the stony shore of a subarctic lake. International Review of Hydrobiology 95: 190-206.

Knudsen R, Klemetsen A. 1994. Infections of Diphyllobothrium dendriticum, D. ditremum (Cestoda), and Cystidicola farionis (Nematoda) in a north Norwegian population of arctic charr (Salvelinus alpinus) during winter. Canadian Journal of Zoology 72: 1922-1930.

Knudsen R, Klemetsen A, Staldvik F. 1996. Parasites as indicators of individual feeding specialisation in arctic charr during winter in northern Norway. Journal of Fish Biology 48: 1256-1265.

Knudsen R, Amundsen P-A, Klemetsen A. 2002. Parasite-induced host mortality: indirect evidence from a long-term study. Environmental Biology of Fishes 64: 257-265.

Lien L. 1978. Energy consumption of ducks on Øvre Heimdalsvatn. Holarctic Ecology 1: 301-303.

Nilsson L. 1978. Den häckande sjöfågelfaunaen i svenska sjörestaureringsobjekt. Vår Fågelvärld 37: 225-239.

Nilsson L. 1985. Bestandsdichte und Vergesellschaftung brütender Wasserfögel Südschwedens in Bezeihung zur Productivität der Seen. Journal für Ornithologie 1126: 85-92.

Persson L, Amundsen P-A, De Roos AM, Klemetsen A, Knudsen R, Primicerio R. 2007. Culling prey promotes predator recovery - alternative states in a whole-lake experiment. Science 316 : 1743-1746. 
Persson L, Amundsen P-A, De Roos AM, Knudsen R, Primicerio R, Klemetsen A. 2013. Density dependent interactions in an Arctic char-brown trout system - competition, predation or both? Canadian Journal of Fisheries and Aquatic Sciences 70: 610-616.

Primicerio R. 2000. Seasonal changes in the vertical distribution of zooplankton in an oligotrophic lake (Lake Takvatn, Norway). Limnologica 30: 301-310.

Seierstad S, Seierstad A, Mysterud I. 1965. Statistical treatment of the 'inconspicuousness problem' in animal population surveys. Nature 206: 22-23.

Strann K-B, Bakken V. 2004. Hekkefuglatlas for Troms. Tromsø. Norsk institutt for naturforskning. 229 p.

Strann K-B, Frivoll V. 2009. Overvåking av hekkende horndykker i Troms. NINA Minirapport 255: 1-14.

Strann K-B, Frivoll V, Heggås J. 2010. Overvåking av hekkende horndykker i Troms. NINA Minirapport 323: 1-15.

Strann K-B, Frivoll V, Heggås J, Hagtvedt M. 2013. Overvåking av hekkende horndykker i Troms. NINA Minirapport 436: 1-20.

Editorial responsibility: Torkild Bakken.

This article is open-access and distributed under the terms of the Creative Commons Attribution-Noncommercial 3.0 Unported License (http://creativecommons.org/licenses/by-nc/3.0/). This permits all non-commercial use, distribution, and reproduction in any medium, provided the original work is properly cited. 